\title{
Pengaruh Current Ratio dan Debt To Equity Ratio terhadap Dividen Payout Ratio pada PT. Mandom Indonesia Tbk di Cibitung
}

\author{
Indri Kharisma \\ Universitas Pamulang
}

\author{
Alamat Surat \\ Email: dosen02474@unpam.ac.id
}

Article History:

Received: 10-Nopember-2020; Received in Revised: 25-Nopember-2020; Accepted: 30-Nopember-2020

\begin{abstract}
ABSTRAK
Penelitian ini bertujuan untuk mengetahui Pengaruh Current Ratio dan Debt to Equity Ratio Terhadap Dividen Payout Ratio Pada PT. Mandom Indonesia Tbk di Cibitung. Metode yang digunakan adalah explanatory research. Teknik analisis menggunakan analisis statistik dengan pengujian regresi, korelasi, determinasi dan uji hipotesis. Hasil penelitian ini Current Ratio tidak berpengaruh signifikan terhadap Dividen Payout Ratio sebesar 2,64\%, uji hipotesis diperoleh t hitung < t tabel atau $(1,696<$ 2,306). Debt to Equity Ratio berpengaruh negatif dan signifikan terhadap Dividen Payout Ratio sebesar 44,7\%, uji hipotesis diperoleh $t$ hitung < t tabel atau $(-2,554<2,306)$. Current Ratio dan Debt to Equity Ratio secara simultan berpengaruh signifikan terhadap Dividen Payout Ratio diperoleh persamaan regresi $\mathrm{Y}=41,675+0,051 \mathrm{X} 1--1,335 \mathrm{X} 2$ dan nilai determinasi sebesar $62,4 \%$, uji hipotesis diperoleh nilai F hitung > F tabel atau $(5,281>4,350)$.
\end{abstract}

Kata kunci: Current Ratio, Debt to Equity Ratio, Dividen Payout Ratio

\section{ABSTRACT}

This study aims to determine the Current Ratio and Debt to Equity Ratio on Dividend Payout Ratio at PT. Mandom Indonesia Tbk in Cibitung. The method used is explanatory research. The analysis technique uses statistical analysis with regression testing, correlation, determination, and hypothesis testing. The results of this study, Current Ratio has no significant effect on the Dividend Payout Ratio of $2.64 \%$, the hypothesis test obtained t count <t table or $(1.696<2.306)$. Debt to Equity Ratio has a negative and significant effect on the Dividend Payout Ratio of 44.7\%; hypothesis testing obtained $t$ count <t table or (-2.554 <2.306). Current Ratio and Debt to Equity Ratio simultaneously significantly affect the Dividend Payout Ratio, the regression equation $Y=41.675+0.051 X 1-$ $1.335 X 2$ is obtained the determination value is $62.4 \%$, hypothesis testing obtained $F$ value $>F$ table or $(5.281>4,350)$.

\section{Keywords: Current Ratio, Debt to Equity Ratio, Dividend Payout Ratio}

\section{PENDAHULUAN}

Perusahaan dapat dinilai dari harga sahamnya. Semakin banyaknya perusahaan yang berdiri di Indonesia, membuat para investor semakin berlomba-lomba menanamkan sahamnya dengan harapan akan memperoleh pengembalian yang baik dari saham yang ditanamnya. Tandelilin (2001) menyatakan bahwa investor yang membeli sejumlah saham saat ini, pada hakikatnya bertujuan untuk mendapatkan dividen (bagian laba setelah pajak yang dibagikan) dan capital gain (selisih dari penjualan saham), sebagai imbalan atas waktu dan risiko yang terkait dengan investasi tersebut. Perusahaan yang baik pasti mampu membagikan dividen. Dividen di suatu perusahaan menjadi pusat 
perhatian bagi investor, dimana kebijakan tersebut akan menjadikan seorang investor akan membeli, mempertahankan atau memutuskan untuk tidak membeli atau menjual saham yang investor miliki. Dividen berasal dari laba perusahaan. Dividen merupakan arus kas yang disisihkan untuk pemegang saham, sedangkan laba ditahan (retaining earning) merupakan salah satu sumber dana yang paling penting untuk membiayai pertumbuhan perusahaan (Riyanto, 2001).

Apabila terdapat kelebihan laba setelah digunakan untuk mendanai seluruh kesempatan investasi yang diterima, kelebihan itu akan di distribusikan kepada pemegang saham dalam bentuk dividen kas dan jika perusahaan memiliki proyek investasi dengan pengembalian melebihi yang diminta, perusahaan akan menggunakan laba untuk mendanai proyek tersebut (James C. Van Horne, 2002). Debt to Equity Ratio (DER) merupakan salah satu faktor yang mempengaruhi dividend payout ratio. Rasio ini mengukur seberapa jauh perusahaan dibiayai oleh hutang, dimana semakin tinggi nilai rasio ini menggambarkan gejala yang kurang baik bagi perusahaan (Sartono 2001). Semakin besar DER (Debt Equity Ratio) menandakan struktur permodalan usaha lebih banyak memanfaatkan hutang-hutang relatif terhadap modal.

Ketika perusahaan memilih menggunakan hutang sebagai modal untuk investasinya, hutang tersebut harus diperhatikan karena penggunaan utang yang terlalu tinggi akan menyebabkan penurunan dividen sehingga sebagian besar keuntungan dialokasikan sebagai cadangan pelunasan utang. Sebaliknya, pada tingkat penggunaan utang yang rendah perusahaan mengalokasikan dividen yang tinggi sehingga sebagian besar keuntungan digunakan untuk kesejahteraan pemegang saham. Selain itu, hutang yang tinggi juga dapat mendekatkan perusahaan terhadap risiko kebangkrutan (Kartika, 2005).

Namun pada kenyataannya, pada PT. Mandom Indonesia Tbk di Cibitung dari 10 tahun terakhir mengalami perkembangan yang menarik cenderung fluktuasi tingkat DER diikuti dengan tingkat yang juga fluktuasi. Keadaan ini seharusnya tidak terjadi karena semakin tinggi tingkat DER, maka semakin rendah tingkat DPR.

Tingginya tingkat DER, dengan semakin tingginya pula tingkat DPR disebabkan karena laba perusahaan menurun, ketika laba menurun, maka kas yang dimiliki perusahaan juga terbatas, namun di sisi lain perusahaan ingin tetap membagikan dividen, sehingga perusahaan melakukan pinjaman yang membuat tingkat utang perusahaan naik. Selain itu, faktor lain yang juga perlu dipertimbangkan dalam besarnya pembagian dividen adalah likuiditas. Likuiditas dihitung dengan menggunakan Current Ratio.

Rasio ini digunakan untuk menghitung seberapa mampu perusahaan dalam membayar hutang lancar dengan asset lancar yang dimilikinya. Berikut ini ihtisar data Current Ratio, Debt to Equity Ratio dan Dividen Payout Ratio PT. Mandom Indonesia Periode Tahun 2010-2019

Tabel 1 Current Ratio, Debt to Equity Ratio dan Dividen Payout Ratio PT. Mandom Indonesia Periode Tahun 2010-2019

\begin{tabular}{|c|c|c|c|}
\hline Tahun & Current Ratio & Debt to Equity Ratio & Dividen Payout Ratio \\
\hline 2010 & $892.8 \%$ & $14.7 \%$ & $85.4 \%$ \\
\hline 2011 & $788.6 \%$ & $13.7 \% \%$ & $63.1 \%$ \\
\hline 2012 & $513.4 \%$ & $17.2 \%$ & $46.1 \%$ \\
\hline 2013 & $674.8 \%$ & $14.9 \%$ & $38.2 \%$ \\
\hline 2014 & $432.9 \%$ & $15.7 \%$ & $48.9 \%$ \\
\hline 2015 & $564.2 \%$ & $21.7 \%$ & $48.7 \%$ \\
\hline 2016 & $672.3 \%$ & $21.2 \%$ & $47.2 \%$ \\
\hline 2017 & $729.9 \%$ & $19.9 \%$ & $39.2 \%$ \\
\hline 2018 & $755.8 \%$ & $28.7 \%$ & $37.5 \%$ \\
\hline 2019 & $585.9 \%$ & $37.7 \%$ & $24.4 \%$ \\
\hline Rata-rata & $661.1 \%$ & $20,5 \%$ & $47,8 \%$ \\
\hline
\end{tabular}

Sumber: PT. Mandom Indonesia, 2019 
Berdasarkan data pada tabel di atas, pencapaian Current Ratio diperoleh rata-rata sebesar 661,1\%. Pencapaian Debt to Equity Ratio diperoleh rata-rata sebesar 20,5\%. Dan Pencapaian Dividen Payout Ratio diperoleh rata-rata sebesar $47,8 \%$.

Perusahaan yang mampu melakukan pembayaran kewajiban jangka pendeknya berarti perusahaan dalam keadaan likuid. Keadaan perusahaan yang mampu membayar jangka pendeknya yang jatuh tempo mengindikasikan bahwa perusahaan mampu juga untuk membayar dividen. Dividen jika dikaitkan dengan likuiditas merupakan arus kas keluar, maka semakin tinggi likuiditas perusahaan berarti makin lancar kemampuannya membayar dividen (Riyanto, 2001).

\subsection{Kajian Pustaka}

\section{Likuiditas}

Likuiditas menurut Agus Sartono (2009) adalah kemampuan untuk membayar kewajiban financial jangka pendek tepat pada waktunya. Likuiditas perusahaan ditunjukan oleh besar kecilnya aktiva lancar yaitu aktiva yang mudah diubah menjadi kas yang meliputi kas, surat berharga, piutang, persediaan. Adapun rumus rasio likuiditas yang digunakan dalam penelitian ini adalah Current Ratio (rasio lancar). Rumus perhitungan CR menurut Irham Fahmi : Current ratio $=$ Current Assets : Current liabilities

\section{Hutang}

Hutang menurut Sofyan Syafri Harahap (2011:211) adalah saldo kredit atau jumlah yang harus dipindahkan dari saat tutup buku ke periode tahun berikutnya berdasarkan pencatatan yang sesuai dengan prinsip akuntansi (saldo kredit bukan akibat saldo negative aktiva). Rasio hutang yang digunakan dalam penelitian ini adalah Debt Equity Ratio (Rasio Utang terhadap Ekuitas. Rumus perhitungan DER menurut James $\mathrm{C}$ van Horne.

\section{Rasio Utang terhadap Equitas = Total Utang : Ekuitas Pemegang Saham}

\section{Dividen}

Dividen menurut Nor Hadi (2013:74) adalah keuntungan yang diberikan pada para pemegang saham yang bersumber dari kemampuan emiten mencetak laba bersih dari operasinya. Rumus yang dipakai dalam menghitung besarnya dividen yang dibagikan adalah :

Dividend Payout Ratio = Dividend Per Share : Earning Per Share

\section{METODE PENELITIAN}

\section{Populasi}

Populasi dalam penelitian ini laporan keuangan selama 10 tahun PT. Mandom Indonesia Tbk di Cibitung

\section{Sampel}

Teknik pengambilan sampling dalam penelitian ini adalah samplel jenuh, dimana semua anggota populasi dijadikan sebagai sampel. Dengan demikian sampel dalam penelitian ini laporan keuangan selama 10 tahun.

\section{Jenis Penelitian}

Jenis penelitian yang dipakai adalah asosiatif, dimana tujuannya adalah untuk mengetahui mencari keterhubungan antar variabel

\section{Metode Analisis Data}

Dalam menganalisis data digunakan uji instrumen, uji asumsi klasik, regresi, koefisien determinasi dan uji hipotesis. 


\section{HASIL DAN PEMBAHASAN \\ 3.1 Hasil \\ Analisis Deskriptif}

Pada pengujian ini digunakan untuk mengetahui besarnya persentase minimum dan maksimum, persentase rata-rata dan standar deviasi dari masing-masing variabel. Adapun hasilnya sebagai berikut:

Tabel 1. Hasil Analisis Descriptive Statistics

\begin{tabular}{lr|r|r|r|r} 
& \multicolumn{2}{c}{ Descriptive Statistics } & & \\
& $N$ & Minimum & Maximum & \multicolumn{1}{c}{ Mean } & Std. Deviation \\
\hline Current Ratio (X1) & 10 & 432.9 & 892.8 & 661.032 & 138.5963 \\
\hline Debt to Equity Ratio (X2) & 10 & 13.7 & 37.7 & 20.534 & 7.5276 \\
\hline Deviden Payout Ratio (Y) & 10 & 24.4 & 85.4 & 47.858 & 16.5788 \\
\hline Valid N (listwise) & 10 & & & & \\
\hline
\end{tabular}

Current Ratio diperoleh nilai minimum sebesar 432,9\% dan nilai maximum 892,8\% dengan rata-rata sebesar 138,6\% dengan standar deviasi 138,59\%. Debt to Equity Ratio diperoleh nilai minimum sebesar 13,7\% dan nilai maximum 37,7\% dengan mean score sebesar 20,53\% dengan standar deviasi $7,52 \%$. Dividen Payout Ratio diperoleh varians minimum sebesar $24,4 \%$ dan nilai maximum $85,4 \%$ dengan rata-rata sebesar 47,85\% dengan standar deviasi $16,57 \%$.

\section{Analisis Verifikatif.}

Pada analisis ini dimaksudkan untuk mengetahui pengaruh variabel independen terhadap variabel dependen. Adapun hasil pengujian sebagai berikut:

\section{Analisis Regresi Linier Berganda}

Uji regresi ini dimaksudkan untuk mengetahui perubahan variabel dependen jika variabel independen mengalami perubahan. Adapun hasil pengujiannya sebagai berikut:

Tabel 2. Hasil Pengujian Regresi Liner Berganda

\begin{tabular}{|c|c|c|c|c|c|}
\hline \multirow[b]{3}{*}{ Model } & \multicolumn{2}{|c|}{ Coefficients $^{\mathbf{a}}$} & \multirow[b]{2}{*}{$\begin{array}{l}\text { Standardized } \\
\text { Coefficients }\end{array}$} & \multirow[b]{3}{*}{$\mathrm{t}$} & \multirow[b]{3}{*}{ Sig. } \\
\hline & \multicolumn{2}{|c|}{$\begin{array}{l}\text { Unstandardized } \\
\text { Coefficients }\end{array}$} & & & \\
\hline & $\mathrm{B}$ & Std. Error & Beta & & \\
\hline $1 \quad$ (Constant) & 41.675 & 22.964 & & 1.815 & .112 \\
\hline Current Ratio (X1) & .051 & .028 & .425 & 1.812 & .113 \\
\hline Debt to Equity Ratio (X2) & -1.335 & .516 & -.606 & -2.585 & .036 \\
\hline
\end{tabular}

a. Dependent Variable: Dividen Payout Ratio (Y)

Berdasarkan hasil pengujian pada tabel di atas, diperoleh persamaan regresi $Y=41,675+0,051 X 1$ 1,335X2. Dari persamaan tersebut dijelaskan sebagai berikut:

1) Konstanta sebesar 41,675 diartikan jika Current Ratio dan Debt to Equity Ratio tidak ada, maka telah terdapat nilai Dividen Payout Ratio sebesar 41,675 point.

2) Koefisien regresi Current Ratio sebesar 0,051, angka ini positif artinya setiap ada peningkatan Current Ratio sebesar 0,051 maka Dividen Payout Ratio juga akan mengalami peningkatan sebesar 0,051 point.

3) Koefisien regresi Debt to Equity Ratio sebesar -1,335, angka ini negatif artinya setiap ada peningkatan Debt to Equity Ratio sebesar -1,335 maka Dividen Payout Ratio juga akan mengalami penurunan sebesar -1,335 point. 


\section{Analisis Koefisien Korelasi}

Analisis koefisien korelasi dimaksudkan untuk mengetahui tingkt kekuatan hubungan dari variabel independen terhadap variabel dependen baik secara parsial maupun simultan. Adapun hasil pengujian sebagai berikut:

Tabel 3. Hasil Pengujian Koefisien Korelasi Current Ratio Terhadap Dividen Payout Ratio.

\begin{tabular}{llrrr} 
& \multicolumn{1}{c}{ Correlations $^{\mathbf{b}}$} & $\begin{array}{c}\text { Current Ratio } \\
(\mathrm{X} 1)\end{array}$ & \multicolumn{2}{c}{$\begin{array}{c}\text { Dividen Payout } \\
\text { Ratio (Y) }\end{array}$} \\
\hline Current Ratio (X1) & Pearson Correlation & 1 & .514 \\
\cline { 2 - 4 } & Sig. (2-tailed) & & .128 \\
\hline Deviden Payout Ratio (Y) & Pearson Correlation & .514 & 1 \\
\cline { 2 - 4 } & Sig. (2-tailed) & .128 & \\
\hline
\end{tabular}

Berdasarkan hasil pengujian diperoleh nilai korelasi sebesar 0,514 artinya Current Ratio memiliki hubungan yang sedang terhadap Dividen Payout Ratio.

Tabel 4. Hasil Pengujian Koefisien Korelasi Debt to Equity Ratio Terhadap Dividen Payout Ratio.

\section{Correlations $^{b}$}

\begin{tabular}{llr|r} 
& & $\begin{array}{c}\text { Debt to Equity } \\
\text { Ratio (X2) }\end{array}$ & \multicolumn{2}{c}{$\begin{array}{c}\text { Dividen Payout } \\
\text { Ratio (Y) }\end{array}$} \\
\hline Debt to Equity Ratio (X2) & Pearson Correlation & 1 & $-.669^{*}$ \\
\cline { 2 - 4 } & Sig. (2-tailed) & & .035 \\
\hline Deviden Payout Ratio (Y) & Pearson Correlation & $-.669^{*}$ & 1 \\
\cline { 2 - 4 } & Sig. (2-tailed) & .035 & \\
\hline
\end{tabular}

Berdasarkan hasil pengujian diperoleh nilai korelasi sebesar -0,669 artinya Debt to Equity Ratio memiliki hubungan yang negatif kuat terhadap Dividen Payout Ratio.

Tabel 5. Hasil Pengujian Koefisien Korelasi Current Ratio dan Debt to Equity Ratio secara simultan Terhadap Dividen Payout Ratio.

\section{Model Summary}

\begin{tabular}{lrr|rrr} 
& & \multicolumn{2}{c}{ Model Summary } & \multicolumn{2}{c}{$\begin{array}{c}\text { Std. Error of the } \\
\text { Estimate }\end{array}$} \\
\hline 1 & $\mathrm{R}$ & R Square & Adjusted R Square & \multicolumn{1}{c}{ Estel } \\
\hline
\end{tabular}

a. Predictors: (Constant), Debt to Equity Ratio (X2), Current Ratio (X1)

Berdasarkan hasil pengujian diperoleh nilai korelasi sebesar 0,790 artinya Current Ratio dan Debt to Equity Ratio secara simultan memiliki hubungan yang kuat terhadap Dividen Payout Ratio.

\section{Analisis Koefisien Determinasi}

Analisis koefisien determinasi dimaksudkan untuk mengetahui besarnya persentase pengaruh dari variabel independen terhadap variabel dependen baik secara parsial maupun simultan. Adapun hasil pengujian sebagai berikut:

Tabel 6. Hasil Pengujian Koefisien Determinasi Current Ratio Terhadap Dividen Payout Ratio. 


\begin{tabular}{|c|c|c|c|c|}
\hline \multirow[b]{2}{*}{ Model } & \multicolumn{3}{|c|}{ Model Summary } & \multirow[b]{2}{*}{$\begin{array}{l}\text { Std. Error of the } \\
\text { Estimate }\end{array}$} \\
\hline & $\mathrm{R}$ & R Square & Adjusted R Square & \\
\hline 1 & $.514^{\mathrm{a}}$ & .264 & .172 & 15.0819 \\
\hline
\end{tabular}

a. Predictors: (Constant), Current Ratio (X1)

Berdasarkan hasil pengujian diperoleh nilai determinasi sebesar 0,264 artinya Current Ratio memiliki kontribusi pengaruh sebesar 2,64\% terhadap Dividen Payout Ratio.

Tabel 7. Hasil Pengujian Koefisien Determinasi Debt to Equity Ratio Terhadap Dividen Payout Ratio.

\section{Model Summary}

\begin{tabular}{|c|c|c|c|c|}
\hline \multicolumn{5}{|r|}{ Std. Error of the } \\
\hline Model & $\mathrm{R}$ & R Square & Adjusted R Square & $\begin{array}{l}\text { Std. Error of the } \\
\text { Estimate }\end{array}$ \\
\hline 1 & $.669^{\mathrm{a}}$ & .447 & .378 & 13.0752 \\
\hline
\end{tabular}

a. Predictors: (Constant), Debt to Equity Ratio (X2)

Berdasarkan hasil pengujian diperoleh nilai determinasi sebesar 0,447 artinya Debt to Equity Ratio memiliki kontribusi pengaruh sebesar 44,7\% terhadap Dividen Payout Ratio.

Tabel 8. Hasil Pengujian Koefisien Determinasi Current Ratio dan Debt to Equity Ratio Terhadap Dividen Payout Ratio.

\section{Model Summary}

\begin{tabular}{lrrrr|r} 
& & & \multicolumn{2}{c}{ Model Summary } & \multicolumn{2}{c}{$\begin{array}{c}\text { Adjusted R } \\
\text { Model }\end{array}$} & R Square & \multicolumn{1}{c}{$\begin{array}{c}\text { Std. Error of the } \\
\text { Estimate }\end{array}$} \\
\hline 1 & R & R Square & .624 & .516 & 11.5328 \\
\hline
\end{tabular}

a. Predictors: (Constant), Debt to Equity Ratio (X2), Current Ratio (X1)

Berdasarkan hasil pengujian diperoleh nilai determinasi sebesar 0,624 artinya Current Ratio dan Debt to Equity Ratio secara simultan memiliki kontribusi pengaruh sebesar 62,4\% terhadap Dividen Payout Ratio, sedangkan sisanya sebesar 37,6\% dipengaruhi faktor lain.

\section{Uji Hipotesis}

\section{Uji hipotesis Parsial (Uji t)} diterima.

Pengujian hipotesis dengan uji t digunakan untuk mengetahui hipotesis parsial mana yang

Tabel 9. Hasil Uji Hipotesis Current Ratio Terhadap Dividen Payout Ratio.

\section{Coefficients $^{\mathrm{a}}$}

Unstandardized

Coefficients

\begin{tabular}{|c|c|c|c|c|c|}
\hline Model & $\mathrm{B}$ & Std. Error & Beta & $\mathrm{t}$ & Sig. \\
\hline $1 \quad($ Constant $)$ & 7.201 & 24.447 & & .295 & .776 \\
\hline Current Ratio (X1) & .062 & .036 & .514 & 1.696 & .128 \\
\hline
\end{tabular}

a. Dependent Variable: Dividen Payout Ratio (Y)

Berdasarkan hasil pengujian pada tabel di atas, diperoleh nilai $\mathrm{t}$ hitung $<\mathrm{t}$ tabel atau $(1,696<$ 2,306), dengan demikian tidak terdapat pengaruh yang signifikan atara Current Ratio terhadap Dividen Payout Ratio. 
Tabel 10. Hasil Uji Hipotesis Debt to Equity Ratio Terhadap Dividen Payout Ratio.

\begin{tabular}{|c|c|c|c|c|c|}
\hline \multirow[b]{3}{*}{ Model } & \multicolumn{2}{|c|}{ Coefficients $^{\mathbf{a}}$} & \multirow[b]{2}{*}{$\begin{array}{l}\text { Standardized } \\
\text { Coefficients }\end{array}$} & \multirow[b]{3}{*}{$\mathrm{t}$} & \multirow[b]{3}{*}{ Sig. } \\
\hline & \multicolumn{2}{|c|}{$\begin{array}{l}\text { Unstandardized } \\
\text { Coefficients }\end{array}$} & & & \\
\hline & $\mathrm{B}$ & Std. Error & Beta & & \\
\hline $1 \quad$ (Constant) & 78.098 & 12.587 & & 6.204 & .000 \\
\hline Debt to Equity Ratio (X2) & -1.473 & .579 & -.669 & -2.544 & .035 \\
\hline
\end{tabular}

a. Dependent Variable: Dividen Payout Ratio (Y)

Berdasarkan hasil pengujian pada tabel di atas, diperoleh nilai t hitung $<\mathrm{t}$ tabel atau $(-2,554<2,306)$, dengan demikian terdapat pengaruh yang negatif dan signifikan atara Debt to Equity Ratio terhadap Dividen Payout Ratio.

\section{Uji Hipotesis Simultan (Uji F)}

Pengujian hipotesis dengan uji $\mathrm{F}$ digunakan untuk mengetahui hipotesis simultan yang mana yang diterima.

Tabel 11. Hasil Uji Hipotesis Current Ratio dan Debt to Equity Ratio Terhadap Dividen Payout Ratio.

\begin{tabular}{|c|c|c|c|c|c|c|}
\hline \multicolumn{7}{|c|}{ ANOVA $^{a}$} \\
\hline \multicolumn{2}{|c|}{ Model } & Sum of Squares & df & Mean Square & $\mathrm{F}$ & Sig. \\
\hline 1 & Regression & 1542.683 & 2 & 771.341 & 5.799 & $.033^{\mathrm{b}}$ \\
\hline & Residual & 931.033 & 7 & 133.005 & & \\
\hline & Total & 2473.716 & 9 & & & \\
\hline
\end{tabular}

Berdasarkan hasil pengujian pada tabel di atas, diperoleh nilai $\mathrm{F}$ hitung $>\mathrm{F}$ tabel atau $(5,281>4,350)$, dengan demikian terdapat pengaruh yang signifikan atara Current Ratio dan Debt to Equity Ratio terhadap Dividen Payout Ratio.

\section{PEMBAHASAN HASIL PENELITIAN}

\section{Pengaruh Current Ratio Terhadap Dividen Payout Ratio}

Current Ratio berpengaruh signifikan terhadap Dividen Payout Ratio dengan korelasi sebesar 0,514 atau memiliki hubungan yang kuat dengan kontribusi pengaruh sebesar $2,64 \%$. Pengujian hipotesis diperoleh nilai $\mathrm{t}$ hitung $<\mathrm{t}$ tabel atau $(1,696<2,306)$. Dengan demikian tidak terdapat pengaruh yang signifikan antara Current Ratio terhadap Dividen Payout Ratio.

\section{Pengaruh Debt to Equity Ratio Terhadap Dividen Payout Ratio}

Debt to Equity Ratio berpengaruh signifikan terhadap Dividen Payout Ratio dengan korelasi sebesar -0,669 atau memiliki hubungan yang lemah dengan kontribusi pengaruh sebesar 44,7\%. Pengujian hipotesis diperoleh nilai $\mathrm{t}$ hitung $<\mathrm{t}$ tabel atau $(-2,554<2,306)$. Dengan demikian terdapat pengaruh negatif dan signifikan antara Debt to Equity Ratio terhadap Dividen Payout Ratio.

\section{Pengaruh Current Ratio dan Debt to Equity Ratio Terhadap Dividen Payout Ratio}

Current Ratio dan Debt to Equity Ratio berpengaruh signifikan terhadap Dividen Payout Ratio dengan diperoleh persamaan regresi $\mathrm{Y}=41,675+0,051 \mathrm{X} 1--1,335 \mathrm{X} 2$, nilai korelasi sebesar 0,790 atau memiliki hubungan yang kuat dengan kontribusi pengaruh sebesar $62,4 \%$ sedangkan sisanya sebesar 37,6\% dipengaruhi faktor lain. Pengujian hipotesis diperoleh nilai $\mathrm{F}$ hitung $>\mathrm{F}$ tabel atau $(5,281>4,350)$. Dengan demikian terdapat pengaruh signifikan antara Current Ratio dan Debt to Equity Ratio terhadap Dividen Payout Ratio. 


\section{KESIMPULAN \\ 4.1 Kesimpulan}

a. Current Ratio berpengaruh signifikan terhadap Dividen Payout Ratio dengan kontribusi pengaruh sebesar 2,64\%. Uji hipotesis diperoleh nilai t hitung < t tabel atau $(1,696<2,306)$.

b. Debt to Equity Ratio berpengaruh signifikan terhadap Dividen Payout Ratio dengan kontribusi pengaruh sebesar 44,7\%. Uji hipotesis diperoleh nilai t hitung $>\mathrm{t}$ tabel atau $(-2,554<2,306)$.

c. Current Ratio dan Debt to Equity Ratio berpengaruh signifikan terhadap Dividen Payout Ratio dengan kontribusi pengaruh sebesar 62,4\% sedangkan sisanya sebesar 37,6\% dipengaruhi faktor lain. Uji hipotesis diperoleh nilai $\mathrm{F}$ hitung $>\mathrm{F}$ tabel atau $(5,281>4,350)$

\subsection{Saran}

a. Bagi perusahaan yang sudah berkomitmen untuk selalu membagikan dividen di tiap tahunnya menjadikan naik turunnya hutang tidak menjadi masalah bagi perusahaan tersebut selama penggunaan hutang selalu diiringi dengan meningkatnya laba perusahaan. Namun, bagi perusahaan yang memiliki tingkat debt equity ratio yang tinggi agar dapat menurunkannya dengan cara mengurangi ketergantungan kebutuhan modal dari hutang jangka panjang, misalnya memenuhi kebutuhan modal dengan menggunakan laba ditahan atau menerbitkan saham baru.

b. Bagi perusahaan yang tingkat current ratio nya rendah agar dapat meningkatkannya dengan cara menekan jumlah hutang lancarnya dan menaikkan aktiva lancarnya, dengan cara menjual aktiva tetap perusahaan atau menaikkan tingkat volume penjualan perusahaan

\section{DAFTAR PUSTAKA}

Agus Harjito \& Martono, (2010) “Manajemen Keuangan” Yogyakarta: Penerbit Ekonisia.

Agus Sartono. (2010). “Manajemen Keuangan Toeri dan Aplikasi”, Edisi keempat, Yogyakarta: Penerbit BPFE.

Algifari. (2015). “Analisis Regresi untuk Bisnis dan Ekonomi”. Yogyakarta: BPFE.

Arikunto, Suharsimi (2014). "Prosedur Penelitian Suatu Pendekatan Praktek”. Jakarta: Rineka Cipta.

Bambang Riyanto, (2011). “Dasar-dasar Pembelanjaan Perusahaan”. Edisi ke empat, BPFE Yogyakarta.

Cahyono, Y., Jihadi, . M., Arifin, . Z., Purnamasari, . W., Musnaini, ., Wijoyo, . H., Fitriaty, ., Putra, . R. S., Putri, . R. A., Muliansyah, . D., Suryani, . P. \& Purwanto, . A. (2020) Do Servant Leadership Influence Market Performance? Evidence from Indonesian Pharmacy Industries. Systematic Reviews in Pharmacy, 11 (9), 439-451. doi:10.31838/srp.2020.9.62

Fahmi, Irham (2012), “Pengantar Manajemen Keuangan” Cetakan pertama. Bandung: Penerbit Alfabeta.

Fahmi, K., Kurniawan, T., Cahyono, Y., \& Sena, A. (2020). Did Servant, Digital and Leadership Influence Market Performance? Evidence from Indonesian Pharmaceutical Industry. Systematic Reviews in Pharmacy, 11(9), 642-653.

Haudi, H. W., \& Cahyono, Y. (2020). Effect Of Product Innovation and Marketing Strategy on Consumer Purchase Decisions In Indonesia's Lightweight Roof Steel Industry. Journal of Critical Reviews, 7(13), 4147-4155.

Imam Ghozali (2017). “Aplikasi Analisis Multivariate Dengan Program SPSS”. Edisi Kelima. Semarang: Badan Penerbit Undip.

Istijanto (2014) “Riset Sumber Daya Manusia”. Jakarta: PT. Gramedia Pustaka 
Jasmani, J. (2018). Pengaruh Kinerja Keuangan Terhadap Harga Saham (Analisis Pada Perusahaan Property dan Real Estate Yang Go Public di Bursa Efek Indonesia. Jurnal Akuntansi Indonesia, 12(2).

Jasmani, J. (2019). The Effect of Liquidity and Working Capital Turnover on Profitability at PT. Sumber Cipta Multiniaga, South Jakarta. PINISI Discretion Review, 3(1), 29-38.

Kasmir (2010), “Analisis Laporan keuangan”, penerbit raja grafindo persada, Jakarta

Kasmir, (2010). “Pengantar Manajemen Keuangan”, Edisi Pertama, Cetakan kedua, Jakarta: Penerbit Prenada Media.

Kasmir. (2012) “Pengantar Manajemen Keuangan”, Edisi Pertama, Cetakan kedua, Jakarta: Prenada Media.

Kharis, Ismu Fadli (2011). "Studi Mengenai Impulse Buying dalam Penjualan Online”. Semarang : Skripsi Universitas Diponegoro

Martono dan Agus Harjito, (2011). “Manajemen Keuangan”, Jakarta: Penerbit Ekonisia..

Munawir (2010), “Analisis Laporan Keuangan”, Edisi Ke Empat, Penerbit Liberty, Yogyakarta.

Nofiana, L., \& Sunarsi, D. (2020). The Influence of Inventory Round Ratio and Activities Round Ratio of Profitability (ROI). JASa (Jurnal Akuntansi, Audit dan Sistem Informasi Akuntansi), 4(1), 95-103.

Nufus, K., Supratikta, H., Muchtar, A., Sunarsi, D. (2020). Analysis of Financial Performance: Case Study of PT. X Employee Cooperative. Utopía Y Praxis Latinoamericana. Año: 25, $\mathrm{N}^{\circ}$ Extra 10, 2020, pp. 429-444

Nuryani,Y. D Sunarsi. (2020). The Effect of Current Ratio and Debt to Equity Ratio on Deviding Growth. JASa (Jurnal Akuntansi, Audit dan Sistem Informasi Akuntansi) 4 (2), 304-312.

Santoso, Singgih (2015). “Menguasai Statistik Multivariat”. Jakarta: PT Elex Media Komputindo.

Sartono, “Manajemen Keuangan Aplikasi Dan Teori”, Edisi Keempat, BPFE, Yogyakarta, 2008.

Sawir, (2003). “Analisis Kinerja Keuangan dan Perencanaan Keuangan Perusahaan”, Cetakan ketiga, Jakarta: Penerbit PT. Gramedia Pustaka Utama.

Siagian, . A. O., Nufus, . K., Yusuf, . N., Supratikta, . H., Maddinsyah, . A., Muchtar, . A., Sari, . W. I., Sunarsi, . D., Akbar, . I. R., Arianto, . N., Purwanto, . A., Noryani, . \& Wijoyo, . H. (2020) A Systematic Literature Review of Education Financing Model in Indonesian School. Systematic Reviews in Pharmacy, 11 (10), 638-644. doi:10.31838/srp.2020.10.96

Sugiyarso, G. dan F. Winarni, "Manajemen Keuangan (Pemahaman Laporan Keuangan, Pengelolaan Aktiva, Kewajiban dan Modal serta Pengukuran

Sugiyono (2017), "Metode Penelitian Administrasi : dilengkapi dengan Metode $R \& D$ ". Bandung: Alfabeta.

Sunarsi, D., Wijoyo, H., Prasada, D., \& Andi, D. (2020, September). Pengaruh Lingkungan Kerja Terhadap Kinerja Karyawan Pada PT. Mentari Persada Di Jakarta. In Seminar Nasional Manajemen, Ekonomi, Akuntansi (Vol. 5, No. 1, pp. 117-123).

Susanti, N., Latifa, I., \& Sunarsi, D. (2020). The Effects of Profitability, Leverage, and Liquidity on Financial Distress on Retail Companies Listed on Indonesian Stock Exchange. Jurnal Ilmiah Ilmu Administrasi Publik, 10(1), 45-52. 